\title{
A CROSS-CULTURAL STUDY OF THE SPEECH ACT OF APOLOGY BY TURKISH AND KURDISH SPEAKERS OF ENGLISH AND THE NATIVE SPEAKERS OF ENGLISH
}

\section{Ahmet CEBi}

Ph.D. Student at Foreign Language Education Department, Eastern Mediterranean University, Famagusta, North Cyprus \& English Teacher, Ministry of National Education, Turkey ahmetcebi84@hotmail.com•https://orcid.org/0000-0002-9719-1004

\section{Dr. Mehmet Veysi BABAYičit}

Lecturer Doctor, at School of Foreign Languages, Batman University, Batman / Turkey m.veysi.babayigit@gmail.com·https://orcid.org/0000-0003-4136-7434

\author{
Article Types / Makale Türü \\ Research Article / Araştırma Makalesi \\ Received / Makale Geliş Tarihi \\ $13 / 05 / 2021$ \\ Accepted / Kabul Tarihi \\ 24/08/2021
}

Doi: https://doi.org/10.26791/sarkiat.937046 


\section{A CROSS-CULTURAL STUDY OF THE SPEECH ACT OF APOLOGY BY TURKISH AND KURDISH SPEAKERS OF ENGLISH AND THE NATIVE SPEAKERS OF ENGLISH}

\section{ABSTRACT}

Communicative competence incorporates the knowledge of syntactic rules and the target language. Speech acts, as the basic units of communication are significant in the linguistics competence in a given language. The current research study explores the speech act of apology utilized by Turkish and Kurdish (non-western cultures) speakers of English and the native speakers of English (western culture) to find out the similarities and differences in the apology strategies they employ when English is used for the medium of communication. The research study revealed significant insights into the most frequently used apology strategies by all three groups: Turkish, Kurdish, and native speakers. In the meantime, the strategies selected and utilized demonstrated that culture and cultural similarities or differences play a major role in the selection of the apology strategies in English for non-native speakers. Likewise, the level of second language proficiency is proven to be a clear indicator of native-like responses. The research findings have also indicated developments in the learners' pragmatic knowledge and awareness. Unlike this study, some further studies may include different social groups incorporating variables such as age, gender, regional and occupational differences for a comprehensive analysis.

Keywords: Speech act of apology, Apology strategies, Turkish, Kurdish, Native speaker, Culture

\section{ÖZÜR SÖYLEMININ TÜRK VE KÜRT INGILIZCE KULLANICILARI ILE ANADILI INGILIZCE OLANLAR TARAFINDAN KULLANIMINA DAIR KÜLTÜRLER ARASI BIR ÇALIŞMA}

\section{öz}

İletişimsel yeterlilik; sözdizimsel kurallar ve hedef dil bilgisini içerir. İletişimin temel birimleri olan söz edimleri, belirli bir dilde dilbilimsel yetkinlik açısından önemlidir. Bu çalışma, İngilizce iletişim aracı olarak kullanıldığında; Türk ve Kürt (bat1lı kültüründen olmayanlar) İngilizce konuşanlar ile anadili İngilizce olan (batı kültüründen olanlar) konuşanların özür stratejilerindeki benzerlikleri ve farklılıkları bulmak için kullandıkları özür söz ediminlerini incelemektedir. Çalışmada, her üç grup tarafından da en sık kullanılan özür stratejileri hakkında önemli bilgiler bulunmuştur: Türk, Kürt ve anadili İngilizce olanlar. Seçilen ve kullanılan stratejiler, anadili İngilizce olmayanlar için İngilizce özür stratejilerinin seçiminde kültür ve kültürel benzerliklerin veya farklılıkların önemli bir rol oynadığını da göstermiştir. Ayrıca, ikinci dil yeterlilik düzeyinin de anadili benzeri yanıtların açık bir göstergesi olduğu kanıtlanmıştır. Araştırma bulguları, öğrencilerin edimbilim bilgisinde ve farkındalığında gelişmelere elde ettiğini de göstermiştir. Bu çalışmanın aksine, bazı ileri araştırmalar, kapsamlı bir analiz için yaş, cinsiyet, bölgesel ve mesleki farklılıklar gibi değişkenleri içeren farklı sosyal grupları içerebilir.

Anahtar Kelimeler: Özür söz edimi, Özür stratejileri, Türk, Kürt, Anadil konuşmacısı, Kültür 


\section{INTRODUCTION}

There has been a significant paradigm shift in the second language teaching and learning theories and more emphasis has begun to be placed on the 'communicative' aspect of language rather than the 'grammatical or structural' aspect of it in order to ensure that the learners can not only acquire the language specific knowledge, but also learn about the non-verbal aspects of the target language so called 'socio-cultural' aspects. This communicative competence was first introduced by Hymes in 1960s and recently it has become the ultimate purpose of language teaching/learning practices. As it was indicated by Hymes (İstifci, 2009), communicative competence encompasses two key aspects; knowledge about the syntactic rules of the target language and the abstract knowledge pertaining to the social and functional rules of the target language. What is significant is that the users should demonstrate the competence of using the language appropriately under different circumstances.

Speech acts are described as the basic units of communication in a given language and considered as crucially significant elements of the linguistic competence in that language. It is indicated that, as part of our communication, we perform speech acts (Schmidt - Richards, 1980). These speech acts are discourse or context bounded and thus the interpretation and the negotiation of speech acts are strongly correlated with the context in which they are used. Speech Act Theory was first defined by Austin in 1962 and it held the purpose of explaining the language as a serious of actions according to the effects of the communication on the listeners and the speakers; assertive, directives, commissives, expressives, and declaratives (Aydin, 2013). The speech act of apology falls under the category of expressives in Speech Act Theory and has been given the upmost importance in the field of pragmatics due to its key role in human communication as an act of 'face saving or politeness'. Goffman (Al-Zumor, 2011) considered apology as a remedial interchange with the ultimate function of altering the meaning of an utterance which might be taken as an offensive act into a socio-culturally and contextually more acceptable one.

Research literature in pragmatics is dominated by the research studies drawing attention on how non-native English speakers are different from the native English speakers and this is the case due to the fact that native speakers have long been considered as the source of reference for pragmatic knowledge and performance (Bardovi-Harling et al., 2008). However, there has been a remarkable paradigm shift in the concept of nativism versus non-nativism with the dramatic increase in the number of non-native English speakers all around the world. In addition to that, the discourse between native and non-native has been expanded which makes it significantly important to analyse the pragmatic production of non-native speakers of 'Englishes' in order to better understand how non-verbal aspects of language are processed and formed by non-native second language users.

Pragmatics is usually referred to as interlanguage pragmatics in second language studies (Kasper - Rose, 2002) due to the fact that it delves into the learners' development and use of pragmatic knowledge in a second language (L2) context. In other words, it investigates how non-native English speakers comprehend, produce and acquire linguistic actions in L2.

\section{LITERATURE REVIEW}

One of the most significant studies on the speech act of apology use in English was carried out to describe the syntactic, semantic and sociolinguistic features of apologies used (Holmes, 1990). Since then, researchers have aimed to expand the scope of the research field and incorporate different languages and compare the apology strategies utilized in different languages; British English speakers were compared to Jordanian Arabic speakers (Bataineh - Bataine, 2008), Persian speakers to British English speakers (Chamani - Zareipur, 2010) and Setswana to English speakers (Kasanga - Lwanga-Lumu, 2007) just to name a few. The common ground for all these studies was the way they had approached the speech act of apology in different languages; investigate the types of apology strategies used and find out how they deviate from each other in different contexts by cross comparing them with the apology strategies utilized by native English speakers. 
As the literature suggests, there is a significant difference between the native and non-native speakers of a language. While the native speakers acquire the verbal and non-verbal aspects of the language simultaneously which allows them to decide on the most appropriate speech act in a given situation, this is not the case when English is learned as a second language or a foreign language. Speech acts are considered as one of the most challenging aspects of learning a second/foreign language (Harlow, 1990; Schmidt and Richards, 1980; Wolfson, 1989) partly because second language users need the socio-pragmatic competence (Istifci, 2009) in order to use the speech acts affectively. Even though speech acts are universal and they are present in almost all languages, their usage shows variations owing to the cultural factors. It is indicated, cross-cultural studies of speech acts have made it clear that second language learners experience significant problems in utilising speech acts when they interact with native speakers (İstifçi, 2009). Antoher stuyd attempting to investigate the Arabic speakers' use of English and the impact of cultural differences on how the speakers performed the speech act of apology indicated that the major difference between the native speakers and non-native Arabic speakers of English in using the apology strategies was due to the religious beliefs, concepts and values (Al-Zumor, 2011). In the meantime, there are other factors affecting the use of apology strategies in different cultures namely the severity of the offence and the contextual differences (Volmer - Olshtain, 1989). A study clearly shows that the choice of the apology strategies is greatly affected by contextual and cross-cultural factors (Olshtain, 1989).

The speech act of apologies has been investigated cross-culturally and the outcomes so far have indicated significant commonalities and deviations in the use of apologies in different cultures. Two studies carried out in an EFL context are the ones by Erçetin (1995) and Tunçel (1999). They investigated the apologies used by EFL learners and found significant differences sourcing from the culture of the participants. This could be explain by Thomas (Istifci, 2009) as he indicates that second language learners might transfer their first/native language speech act rules into their L2 which might cause 'pragmalinguistic failure' or their view on the appropriateness of the linguistic behaviour might result in 'sociopragmatic failure'. Such an interaction was made clear in a study conducted by Olshtain and Shoshana (Istifci, 2009) with Hebrew native speakers and Hebrew learners. The striking result of the study indicated that the proximation of norms used by the non-native Hebrew speakers were very close to the native Hebrew speakers when there were significant similarities in rules in both languages and it was the opposite when the languages had peculiar or unique rules. Their study also revealed that another significant factor that affected the learners' performance was the amount of time they had spent in the culture of the target language. It was made clear that exposure to the target culture would enhance the socio-pragmatic competence. This was confirmed that the interaction with the target culture and language is crucially important to develop the pragmatics of the target culture (Shardakova, 2005). Another study conducted with 129 EFL learners at Anadolu University, 50 native speakers and 44 native Turkish speakers suggested that there was a remarkable transfer from the L1 into L2 in terms of the apologies used (Tunçel, 1999). He also made it clear that the learners transferred the 'sociocultural norms' of Turkish into English when they responded to the situations in which they had to carry out the act of apology. In another study attempting to investigate the apology strategies used by Iranian EFL learners and Malaysian ESL learners disclosed that the differences in the apology strategies used by the respondents were mostly due to their cultural differences as certain aspects of language such as the act of apology is culture-bounded (Farashaiyan - Yazdi Amirkhiz, 2011). Meanwhile, there were similarities because of the fact that both Iranian and Malaysian cultures are so called 'non-western' cultures and share similar sociocultural values in terms of social hierarchy.

\subsection{CROSS-CULTURAL SPEECH ACTS REALISATION PROJECT}

The most extensive analysis of the content of apologies has been carried out by the Cross-Cultural Speech Acts Realisation Project-CCSARP (Shoshana - Olshtain, 1984) as an attempt to develop a measure of sociocultural competence in the learning of a second language (Cohen - Olshtain, 1981) which was developed into a more sophisticated analysis of the realisation of speech acts of requests and apologies across cultures. Five strategies that comprise the 'apology speech act set' which could be utilized to apologise have 
been proposed by the CCSARP; illocutionary force indicating device (IFID), an explanation, an expression of responsibility for the offence, an offer for repair, and a promise of forbearance (Olshtain - Cohen, 1983).

Research studies have investigated apologies in the field of cross-cultural pragmatics to compare the use of apology speech acts between native English speakers and the speakers of other languages like Persian (Eslami-Rasekh, 2004), Danish (Trosborg, 1995), Spanish (Garcia, 1989), Turkish (Tunçel, 1999), etc. Most of these cross-cultural studies were carried out within the CCSARP project to compare across languages the realisation patterns of two speech acts; request and apologies, to establish the similarities and differences between native and non-native speakers' realisation of the patterns in these two acts (Shoshana - Olshtain, 1984). Inter-language apology studies, however, generally investigate the production and perception of apologies by non-native language learners. Their aims so far have been to compare the use of apologies in English with other languages. The studies mentioned above mostly investigated the western cultures. Their definition of apology has been against the norms of western sociocultural system which does not necessarily share the same characteristics in other cultures or so called 'non-western' cultures (Liebersohn et al., 2004).

\subsection{INTERLANGUAGE STUDIES ON APOLOGY}

The primary concern of the interlanguage studies on apology is to investigate the second language learners' production of the target language either as a second language or as a foreign language. This is mostly done in the form of comparing the native speakers and the non-native speakers of English and the way they employ the speech act of apology in English. A study conducted by Trosborg (1987) to compare the Danish learners of English and native speakers of English to unveil the similarities and/or differences in the use of the speech act of apology revealed that there were significant differences in the non-native speakers' use of modality markers compared to the native speakers. Another study was conducted to investigate the three aspects of the apology strategies; frequency, distribution and function, between Chileans and Australians clearly indicated that there were remarkable similarities in the 'frequency' of the apology strategies, but gender was one of the social elements that stood out as a factor making a great impact on the apology strategies used (Cordella, 1991). Maeshiba et al. (1996), on the other hand, explored two distinct factors: contextual factors and the proficiency of learners, that could potentially contribute to the "pragmatic transfer' from Japanese to English. The study revealed that the lower the level of proficiency, the higher the rate of pragmatic transfer was. In the meantime, a similar study with Korean and EFL speakers was conducted (Kim, 2001). The findings of this study clearly indicated that there were certain social factors such as social distance, age, gender, etc., that influenced the pragmatic transfer from the first language to English.

\section{SIGNIFICANCE OF THE STUDY}

A significant number of research studies were carried out to investigate the speech act of apology in English and other languages to explore the similarities and differences. However, it is worth mentioning that most of these research studies are based on the languages of the western cultures which indicates the necessity to focus more on the non-western cultures and their use of English. Therefore, the present study focused Turkish and Kurdish speakers of English as non-western cultures. It intends to identify and categorise the types of apology strategies used among Turkish and Kurdish participants when they utilise English as the medium of communication. Considering the fact that Turkish and Kurdish people have lived together for centuries and their cultures have remarkably a lot in common, the present study would reveal important insights into the similarities and differences in the apology strategies that they employ when they use English as the medium of communication. Therefore, the present research study aims to explore the following research questions;

1. To what extent the typical apology strategies produced by Turkish and Kurdish speakers of English show similarities and/or differences compared to the ones produced by the native speakers? 
2. To what extent the patterns of semantic formulas used by Turkish and Kurdish speakers of English to apologize are similar or different compared to the ones uttered by the native speakers?

\section{METHODOLOGY}

\subsection{PARTICIPANTS}

There were four Turkish, four Kurdish speakers of English, and four native speakers of English involved in this research study. All of the participants were pursuing their postgraduate studies at the time of the research study. Due to the fact that there were limited number of potential participants for the research study designed, judgmental sampling (Marshall, 1996), which is also referred to as non-probability sampling, was applied in this research study. In other words, the researchers selected the most productive participants based on his personal judgment.

Table 1 : Participant profile

\begin{tabular}{lll}
\hline Participants & Age range & Visited an English speaking country? \\
\hline Kurdish Participants & & \\
Participant 1 & $24-28$ & never visited an English speaking country \\
Participant 2 & 32 and over & never visited an English speaking country \\
Participant 3 & $28-32$ & never visited an English speaking country \\
Participant 4 & 32 and over & visited an English speaking country \\
Turkish Participants & & \\
Participant 5 & 32 and over & never visited an English speaking country \\
Participant 6 & $24-28$ & visited an English speaking country \\
Participant 7 & $24-28$ & visited an English speaking country \\
Participant 8 & $29-32$ & visited an English speaking country \\
Native English Speakers & & \\
Participant 9 & 32 and over & N/A \\
Participant 10 & 32 and over & N/A \\
Participant 11 & $29-32$ & N/A \\
Participant 12 & $24-28$ & N/A \\
\hline
\end{tabular}

In addition to the Turkish and Kurdish participants, four native speakers of English were also included in the research study to investigate the speech act of apology from their perspective and cross compare their responses with the ones provided by non-native speakers.

\subsection{DATA COLLECTION INSTRUMENTS}

A Discourse Completion Test (henceforth DCT), was adopted to collect the data in this research study (Al Ali, 2013), and this adopted DCT constituted the basic path for the methodology of the current study. Before completing the test, all groups (Turkish, Kurdish, and the native speakers) were given the informed consent form and kindly requested to announce their voluntary participation. The DCT consisted of two sections. The first section aimed to collect the background information about the participants to identify their age, exposure to the target language in ESL or EFL contexts, and language study background. The second section included eight different scenarios, four highly formal and four remarkably less formal situations, in which the participants were required to utilise apology strategies. It was crucially important that the participants provided the most natural responses that they would potentially produce. Therefore, they were kindly reminded to reflect on the scenarios just the way they would in real life. The participants were able to complete the DCT at their own pace. They were also informed that any queries that they might have before, during or after the test would be addressed by the researcher. 
Some of the participants ( 3 of the Turkish participants and four of the Kurdish participants) received a hard copy of the Discourse Completion Test (DCT) whereas others (native English speakers and one of the Turkish participants) completed the test online.

\subsection{DATA ANALYSIS}

The major aim of the data analysis was to determine the similarities and the differences of the apology strategies used by Turkish and Kurdish speakers. This called for initially determining what the range of apology patterns were among Turkish and Kurdish speakers of English for the given scenarios and then the same procedure was followed for the native speakers of English. In other words, based on the following research questions, the current study was attempted to be analyzed;

1. What are the similiarites and differences of the apology strategies and patterns adopted by Turkish and Kurdish particpants?

2. To what extent are the patterns of semantic formulas used by the Kurdish and Turkish participants similar?

3. What is the role of culture on the selection and the use of apology strategies?

In order to categorise the apology strategies and patterns used by the participating groups, a mode was much needed. A careful analysis of the available models revealed that the one used by Farashaiyan and Yazdi Amirkhiz (2011) which incorporated the Fraser's list of semantic formulas (1979), Cohen and Olstein (1981), Olstein and Cohen (1983) and the CCSARP coding manual (Shoshana et al., 1989) was the most suitable one for this study.

(1) Illocutionary Force Indicating Devices (IFIDs)

a. An expression of regret, e.g. I'm sorry

b. An offer of apology, e.g. I apologise

c. A request for forgiveness, e.g. Excuse me/Forgive me/ Pardon me

(2)Explanation or Account any external mitigating circumstances, 'Objective' reasons for the violation, e.g. The traffic was terrible

(3) Taking on responsibility

a. Explicit self-blame, e.g. It is my fault/my mistake

b. Lack of intent, e.g. I didn't mean it

c. Expression of self-deficiency, e.g. I was confused/I didn't see you/I forgot

d. Expression of Embarrassment, e.g. I feel awful about it

e. Self-dispraise, e.g. I'm such a dimwit!

f. Justify hearer, e.g. You're right to be angry

g. Refusal to acknowledge guilt

h. Denial of responsibility, e.g. It wasn't my fault

i. Blame the hearer, e.g. It's your own fault

j. Pretend to be offended, e.g. I'm the one to be offended

(4) Concern for the hearer, e.g. I hope I didn't upset you/Are you all right?

(5) Offer of Repair, e.g. I'll pay for damage

(6) Promise of Forbearance, e.g. It won't happen again 


\section{ETHICAL CONSIDERATIONS}

The research participants were informed about the purpose and the scope of the research study in writing and orally. Participation in this research study was completely voluntary and the participants were made aware of this. As some of the participants took part in this study by answering the online survey prepared by the researcher, they were asked to read the consent form carefully and confirm their voluntary participation before responding to the survey. The participants were ensured that the research data would be kept strictly confidential and their identity would not be revealed when the research findings are reported.

\section{FINDINGS}

\subsection{APOLOGY STRATEGIES USED BY TURKISH, KURDISH AND NATIVE ENGLISH SPEAKERS}

The first part of the findings section of this paper presents the frequency of apology strategies employed by 12 participants: 4 Kurdish speakers of English, 4 Turkish speakers of English and 4 native English speakers who were asked to respond to 8 apology-provoking situations in the discourse completion test. The overall frequency of semantic formulas of each group as displayed in the table below has been provided to identify the general tendencies in the application of apology strategies by different groups.

Table 2: Frequency of apology strategies used by Turkish, Kurdish and native English speakers.

\begin{tabular}{|c|c|c|c|}
\hline Apology Strategies & $\begin{array}{l}\text { Kurdish } \\
\mathrm{n}: 4\end{array}$ & $\begin{array}{l}\text { Turkish } \\
\mathrm{n}: 4\end{array}$ & $\begin{array}{l}\text { N. Speaker } \\
\mathrm{n}: 4\end{array}$ \\
\hline
\end{tabular}

(1) Illocutionary Force Indicating Devices (IFIDs)
a. An expression of regret
25
$41.67 \% \quad 24$
$24 \quad 36.36 \% \quad 28$
$53.85 \%$
b. An offer of apology
3
$5 \%$
$3 \quad 4.55 \% \quad 1$
$1.92 \%$
c. A request for forgiveness,
3
$\% 5$
$2 \quad 3.03 \%-$

(2)Explanation or Account

Any external mitigating circumstances

8

$13.33 \% 8$

$12.12 \% \quad 8$

$15.38 \%$

(3) Taking on responsibility
a. Explicit self-blame
b. Lack of intent
c. Expression of self-deficiency
d. Expression of Embarrassment
e. Self-dispraise
f. Justify hearer
g. Refusal to acknowledge guilt
(4)Concern for the hearer
(5) Offer of Repair
(6)Promise of Forbearance
All Strategies Combined

$6.67 \%$
$6.67 \%$
$3.33 \%$
$3.33 \%$
-
-
-
-
$10 \%$
$5 \%$
100

3

$4.55 \% \quad 1$

$1.92 \%$

$\begin{array}{llllll}4 & 6.67 \% & 5 & 7.58 \% & 1 & 1.92 \%\end{array}$

2

2

$-$

$-$

The findings revealed that all three groups employed fourteen different strategies out of fifteen listed in the table. None of the participating groups demonstrated any sign of the strategy so called 'justifying the hearer'. When we analyze the overall tendencies in the use of apology strategies, the first thing that captures our attention is the frequency of the semantic formulas used by the three distinct groups; 60 frequencies of semantic formulas were employed by Kurdish speakers of English, 66 frequencies of semantic formulas used by Turkish speakers of English, and 52 frequencies of semantic formulas utilized by the native English speakers. Out of 66 apology strategies used by Turkish speakers, 29 of them were the illocutionary force 
indicating devices (IFIDs) followed by Kurdish participants with the ratio of 31 out of 60 apology strategies. Native English speakers had the lowest ratio of 29 out of 52 apology strategies dedicated to the IFIDs.

A careful analysis of the results revealed that the most commonly used apology strategy by all three groups was the 'expression of regret'. Kurdish speakers used the 'expression of regret' with 25 frequencies (41.67\%) of semantic formulas. Likewise, Turkish speakers of English used 24 frequencies (36.36\%) of semantic formulas as an expression of regret. The highest frequency of semantic formulas of the expression of regret ( $\mathrm{f}=28-58.85 \%$ ) was utilized by the native English speakers. This clearly demonstrated the close proximity between the Turkish and Kurdish speakers of English in terms of the use of the most basic apology strategy which is the expression of regret. Whereas, the frequency $(\mathrm{f}=28)$ of the semantic formulas used by the native English speakers $(53.85 \%)$ was the highest among all three groups. An in-depth analysis of the semantic formulas that all three groups used to express their regret revealed that the individual language users utilized 'intensifiers' such as adverbs to alter the IFIDs they used. In most cases, it was observed that all individual participants, regardless of the group they belong to, used such intensifiers when they expressed their regret. For example, all participants, except for one of the Turkish participants, used an adverb (e.g., so, really, etc.) to intensify the IFID when the situation under which they were expected to produce an apology was highly formal (e.g., Scenario 8). Meanwhile, it is worth mentioning that native speakers of English used 'really' as an intensifier while non-native English speakers preferred 'so' mostly.

Another striking point that could easily be observed in Table 2 is the frequency of the semantic formulas of 'explanation or account'. The frequency $(\mathrm{f}=8)$ of the semantic formulas used to provide an explanation or an account was the same for all three groups. When the individual responses were analyzed carefully, out of eight responses provided by the Kurdish speakers, four of those semantic formulas were utilized to provide explanation for the scenario number one which comprises of a significantly formal situation. This was observed among the Turkish participants and similarly, three out of eight semantic formulas provided as an explanation or an account was for the first scenario. Native speakers demonstrated the same tendency as the Kurdish speakers of English and used four of the semantic formulas to provide an explanation or an account for the first scenario. Among all three groups, following up on the first scenario, the one that received 'explanation' as the most frequent semantic formula was the seventh scenario which was remarkably formal just as the first scenario. The other scenarios in which the participants provided an explanation (e.g., the fifth scenario) were mostly formal scenarios which could lead to the conclusion that participants showed the tendency to provide an explanation or an account under the circumstances where there was some kind of formality between the speaker and the interlocutor. It was evident in the data that Kurdish, Turkish and the native speakers displayed similar tendencies pertaining to the situations under which they provided an explanation or an account as part of their apology strategies.

Having mentioned the similarities, it would be necessary to highlight the striking differences among these groups. The most remarkable one is the frequency of the semantic formulas employed by these groups as an 'offer of repair' as part of the apology strategies used. It was observed that Turkish speakers had the highest frequency $(\mathrm{f}=15)$ of the semantic formulas $(22.73 \%)$ used to indicate an offer of repair whereas Kurdish speakers $(\mathrm{f}=6,10 \%)$ and native speakers $(\mathrm{f}=8,15.38 \%)$ had remarkably less use of this strategy. In addition to that, it was also observed that Kurdish speakers of English were the only ones who used two distinct apology strategies which other groups did not use at all; the expression of embarrassment and the promise of forbearance. On the contrary, Kurdish speakers of English did not utilise 'self-disparity' and 'refusal to acknowledge quilt' while Turkish speakers of English and the native English speakers did. The next section will further explore the apology strategies utilized by the participating groups.

\subsection{PATTERNS OF SEMANTIC FORMULAS USED BY TURKISH, KURDISH, AND NATIVE ENGLISH SPEAKERS}

In this section, the patterns of apology strategies used by the three distinct groups will be analyzed to identify the similarities and the differences in their use of these strategies under different circumstances. 
The following table outlines the most commonly used patters of semantic formulas by Turkish, Kurdish, and the native English speaking participants.

Patterns were encoded using the semantic formulas that were taken from the model (Cohen - Olstein, 1981; Farashaiyan - Yazdi Amirkhiz, 2011; Fraser, 1979; Olstein - Cohen, 1983; Shoshana et al., 1989).

Table 3

\begin{tabular}{lllllll}
\hline Apology Strategies & \multicolumn{2}{l}{ Kurdish n:4 } & \multicolumn{2}{l}{ Turkish n:4 } & \multicolumn{2}{l}{ N. Speaker n:4 } \\
\hline & $\mathrm{F}$ & $\%$ & $\mathrm{~F}$ & $\%$ & $\mathrm{~F}$ & $\%$ \\
Expression of regret & 5 & $20 \%$ & 3 & $10.71 \%$ & 12 & $40 \%$ \\
Expression of regret + explanation & 4 & $16 \%$ & 9 & $32.14 \%$ & 6 & $20 \%$ \\
Expression of regret +another strategy & 4 & $16 \%$ & 4 & $14.29 \%$ & 3 & $10 \%$ \\
Expression of regret + another strategy + another & 9 & $36 \%$ & 7 & $25 \%$ & 6 & $20 \%$ \\
strategy & & & & & & \\
a strategy +explanation & 3 & $12 \%$ & 3 & $10.71 \%$ & 1 & $3.33 \%$ \\
explanation + another strategy + another strategy & - & $0 \%$ & 2 & $7.14 \%$ & 2 & $6.67 \%$ \\
All strategies combined & 25 & $100 \%$ & 28 & $100 \%$ & 30 & $100 \%$ \\
\hline
\end{tabular}

Patterns of semantic formulas used by Turkish, Kurdish and native English speakers

The followings are the examples of the most commonly used patterns of semantic formulas employed by the participants:

1. Expression of regret-"So sorry." (Participant 1)

2. Expression of Regret + Explanation-"I am so sorry, but suddenly I was called to an important meeting so I couldn't come."(Participant 5)

3. Expression of Regret + Another strategy- "I'm really sorry but I had an important commitment come up last minute." (Participant 12)

4. Expression of Regret + another Strategy + another Strategy- "I am so sorry. How can I compensate for it? Just tell me. I will be happy to do it. It is all my fault."(Participant 6)

5. Explanation+ Another Strategy + (Another Strategy)- "I couldn't participate your lesson as I was ill and actually the first time I skipped your class and forgot to bring my medical report. Sorry for that." (Participant 5)

"I'm sure it was an accident, but I'm sorry. Is there any way I can help?" (Participant 11)

As it could be seen in the excerpts, the most frequent patterns of semantic formulas used by the Kurdish speakers of English were "Expression of regret + another strategy (other than explanation)" with the frequencies of $9(36 \%)$. When all groups were analyzed in terms of their use of this pattern of semantic formula, it is evident that Kurdish participants used this pattern more than the Turkish participants $(\mathrm{f}=7$, $25 \%)$ and the native English speaking participants $(\mathrm{f}=6,20 \%)$. This was also reported in a research study analyzing the apology speech act of Kurdish children (Sadeghi, 2013). It was evident in that research study that the most frequently used formula by Kurdish speakers was an IFIED or the most direct apology strategy. However, it was also observed that unlike Turkish and native English speaking participants, Kurdish participants did not use the pattern of semantic formula which was initiated by 'an explanation' followed by a single or multiple apology strategies. While the Turkish participants and the native English speaking participants utilized this pattern of semantic formula with the frequencies of 2 for each group (Turkish- 7.14\% and Native English Speakers- 6.67\%), Kurdish speakers did not use this pattern at all. On the other hand, the most frequent pattern of semantic formula utilized by the Turkish speakers of English was the 'expression of regret + explanation' with the frequencies of 9 (32,14\%). Native English speaking participants formed the second group that used this pattern of semantic formula the most $(f=6,20 \%)$ and the group that used it the least was the Kurdish participants with the frequencies of 4 (16\%). 
The most striking result that potentially distinguished the native speakers' apology strategies from the Kurdish and Turkish speakers' ones was the pattern of semantic formula that they used the most: expression of regret. It was revealed that this was the most frequent patter of semantic formula employed by the native English speaking participants with the frequencies of $12(40 \%)$ whereas the Turkish participants used it with the frequency of $5(10.71 \%)$ and the Kurdish speakers with the frequencies of $3(10.71 \%)$. It was evident that non-native speakers displayed the tendency to utilize extra strategies followed by the most basic one which is the 'expression of regret'. On the other hand, it was evident that non-native English speaking participants were in favor of the patterns of semantic formulas which was initiated by an expression of regret followed by another apology strategy such as offer of repair, expression of self-deficiency, explicit self-blame..etc. Although the same pattern was used by the native speaker participants $(f=6)$, the frequency was relatively less compared to the Turkish $(\mathrm{f}=9)$ and Kurdish $(\mathrm{f}=7)$ participants.

Even though the distribution of the patterns of semantic formulas used to apologize is uneven, we could easily observe that participants, regardless of whether they are native English speakers or non-native English speakers, tend to utilize the semantic formula of 'expression of regret + another apology strategy'. Such tendencies were clearly observed for scenarios in which the situation is fairly formal and thus requires the use of apology strategies accordingly. The aforementioned 'expression of regret + another apology strategy' formula was frequently used for the first scenario in which a university lecturer is required to apologize from a student who he/she does not know personally. The systematic analysis of the patterns of the semantic formulas revealed that 7 out of 12 participants ( 2 of the Turkish participants, 2 of the Kurdish participants, and 3 of the native speaker participants) employed the exact pattern of semantic formula: expression of regret followed by an explanation.

\section{DISCUSSION}

A careful analysis of the data presented in Table 1 revealed that the number of apology strategies used by the Kurdish, Turkish, and native English speaking participants were all the same. They all used ten different apology strategies to respond to the eight scenarios provided. Among all these strategies utilized, the three most commonly used strategies were the "Expression of apology/ regret", "Offering repair" and "Explanation". Such findings were confirmed in other research studies (Alfattah, 2010; Cohen - Olshtain, 1981; Intachakra, 2004; Prachanant, 2006; Reiter, 2000; Tamanaha, 2003) in which the research findings indicated that these three apology strategies were the most frequently used ones independent from the users' linguistic background. Having said that, it was clearly evident that all three groups employed a range of different semantic formulas to carry out the apologies. Non-native speakers demonstrated the tendency to utilise multiple strategies to apologise in different situations whereas native speakers relied mostly on one IFID which is the 'expression of regret'. This was confirmed in the study which revealed that British speakers showed the tendency to use one IFID while Persians utilized multiple apology strategies in their attempts conducted (Chamani - Zareipur, 2010). Having said that, it was also evident in the research findings that the patterns of semantic formulas used by the Kurdish and Turkish participants were quite similar, if not the same. This could be explained with the notion that both groups share similar cultures values and they are non-western cultures. As indicated, apology as a speech act could be universal and present in different languages (Aydin, 2013), but there are significant cultural differences in the way such acts are performed by means of the strategies employed by the language users.

The fact that illocutionary force indicating devices (IFIDs) were the most frequently used patterns of semantic formulas by all three groups in this research study, their function as a compulsory unit in the speech act of apology is obvious. Even though all three groups employed the illocutionary force indicating devices (IFIDs) in almost all apology situations, there was a significant difference in the way they utilized them. Turkish and Kurdish participants, as non-native English speakers, had the tendency to modify the semantic formulas by using 'intensifiers'. 10 out of 25 semantic formulas used by the Kurdish participants were modified by intensifiers. Similarly 12 out of 24 semantic formulas used by the Turkish participants for the same purpose had intensifiers. However, the ratio is rather low in native English speaking participants 
(10 out of 28 were modified using intensifiers). Similar findings were reported to indicate that non-native speakers employ more intensifiers in their apologies compared to native speakers (Aydin, 2013). The statistical data clearly shows that although there was a difference between the native speakers and the non-native speakers in their use of intensifiers to modify the apologies they used, the gap in between was not great. This could be explained by the fact that the non-native English speaking participants were all postgraduate students and thus had a remarkably good level of English. In the research study, it was revealed that advanced level learners used similar apology strategies as native speakers (Aydin, 2013). In the meantime, it was also reported that education as an independent variable has profound impact on the selection and the use of apology strategies (Ghanbari, et al., 2015). Last but not least, it was indicated that the level of education could be considered as a significant factor affecting our lives in many ways, including the apology behaviors (Ozyildirim, 2010).

Meanwhile, it is crucially important to highlight another factor that affects the pragmatic competence of the language users which is the exposure to the target culture. Out of eight non-native English speaking participants, only two of them had ever been to a country where English is spoken as the first language. The significance of the exposure to the target culture is evident in the study conducted to identify the apology strategies used by the Japanese learners of English who had a chance to learn the language in the target language context (Kondo, 1997). It was revealed that the pragmatic competence was greatly affected by the exposure to the target language in the actual context where it is used. Similar findings were reported to stress the importance of the exposure to the target culture and the language on the development of the pragmatic competence (Shardakova, 2005).

On the other hand, the impact of the cultural differences and similarities on the apology strategies used was evident in this research study too. It was revealed that taking on the responsibility was one of the apology strategies employed by the Turkish and Kurdish participants only. The research study conducted by Sadeghi (2013) to explore the apology strategies used by Persians and Kurdish children revealed that taking on responsibility was one of the most common apology strategies Kurdish participants employed. Therefore, bearing in mind the fact that both Kurdish and Turkish cultures are non-western cultures, the cultural similarities between the Turkish and Kurdish participants could be the reason behind such a similarity.

\section{PEDAGOGICAL IMPLICATIONS}

The research study has revealed significant insights into how speech acts are utilized by the native and non-native English speakers who have different cultural and linguistic backgrounds. This is significant in the sense that the understanding of the the way the speech act of apology is employed by language users, more specifically similarities and differences among different cultures, would provide useful insights into the teaching and learning practices. The research findings could potentially raise the awareness of the language teachers and language learners about the significance of the pragmatic knowledge of the target language as this is the corner stone of developing the pragmatic competence that is much required to communicate more effectively in the target language. An understanding of the impact of the linguistic and cultural background on the development of such pragmatic competencies could inform the language teaching practices of the teachers in the classroom. Indeed, it signifies the importance of authenticity in language teaching as the learners need exposure to the actual use of language rather than limiting themselves to the coursebooks prescribed. Having said that, language teachers could be more flexible in this regards and provide opportunities for their learners to expose to the target culture and language by means of the information and communication technologies (ICT), the internet, social media, telecollaboration, etc. Integration of such tools in language teaching process would enhance the quality of the language teaching/ learning process and help develop the pragmatic competence of the learners which is crucially important in using the target language effectively.

Speech acts are essential components of the communicative competence second language learners need to possess as the intended meaning in a cultural context is carried by means of such components. As noted, 
compared to grammatical errors, pragmatic errors are considered as more serious errors by native speakers and thus less tolerated (Wolfson, 1983). However, this does not change the fact that the acquisition of pragmatic competence is quite challenging even for advance level second language learners (Tanaka, 1997). Therefore, it is important that teachers provide opportunities for learners to acquire such competencies in the classroom. In other words, explicit teaching of the speech act of apology in a language class could yield significantly positive results allowing the learners to internalize such language structures and use them accordingly. The study carried out by Ishihara (2007) proved the effectiveness of the explicit instructions in the development of the students' awareness and the use of the speech act of compliment. This clearly indicates the invaluable contribution of explicit instructions/teaching practices on the acquisition of the speech acts and thus enhancing the pragmatic competence of the language learners.

\section{CONCLUSION AND FUTURE DIRECTIONS}

The present study aimed at identifying and comparing the apology strategies used by Kurdish and Turkish speakers of English and the native English speakers. The data were collected from a DCT questionnaire comprising of eight different situations in which the respondents were required to utilize an apology strategy. The DCT was used to find out the similarities and differences in the use of apology strategies by these three distinct groups. The finding of this study demonstrated that both groups used similar patterns of semantic formulas to form their apology strategies. 'Expression of regret' was the most frequently used apology strategy for all three groups. This was followed by 'explanation' and 'offer of repair'. The study also revealed that unlike non-native speakers of English, native speakers showed the tendency to use 'expression of regret' a lot more than the other apology strategies. However, non-native speakers of English preferred using this strategy along with another strategy such as explanation, offer of repair, lack of intent, etc. In the meantime, the research study revealed certain similarities between the Turkish and Kurdish participants' use of apology strategies which could be explained by the cultural similarities. Therefore, the current study provides valuable information about the impact of such cultural similarities and differences on the selection and the use of apology strategies.

As it is indicated, there has not been many research studies conducted in the Turkish context to explore the strategies they employ to carry out the speech act of apology (Aydin, 2013) and thus, it is still an area for researchers to study and explore more. This would ultimately help us understand the complex nature of the speech act of apology. The present study may have much to tell about apology strategies utilized by Turkish, Kurdish and native English speaking participants who are post-graduate university students, but not so much about other social groups. Future research should aim at collecting data from a larger-scale survey and more factors such as education, gender, regional, and occupational differences, should be considered in order to attain a general profile of the apology behavior of the Turkish and Kurdish speakers of English.

\section{DISCLOSURE STATEMENT}

No potential conflict of interest was reported by the authors 


\section{REFERENCES}

Al Ali, Shatha Ahmed S. 'Saying Sorry': Pragmatics and the use of Positioning Theory in a Study of Apology Behaviour of Saudi and Australian Women. Canada: Victoria University, Ph. D Thesis, 2018.

Alfattah, Mohammed. “Apology strategies of Yemeni EFL university students”. MJAL 2/3 (2010), 223-249.

Al-Zumor, Abdul Wahed Qasem Ghaleb. "Apologies in Arabic and English: An inter-language and cross-cultural study". Journal of King Saud University-Languages and Translation 23/1 (2011), 19-28.

Aydin, Mehmet, Cross cultural pragmatics: A study of apology speech acts by Turkish speakers, American English speakers and advance nonnative speakers of English in Turkey. Mankato: Minnesota State University, Ph. D Thesis, 2013.

Bardovi-Harlig, Kathleen et al. 'The Use of Conventional Expressions of Thanking, Apologizing, and Refusing'. Selected Proceedings of the 2007 Second Language Research Forum, 113-130. MA: Cascadilla Proceedings Project Somerville, 2008.

Bataineh, Rula Fahmi - Bataineh, Ruba Fahmi. "A cross-cultural comparison of apologies by native speakers of American English and Jordanian Arabic”. Journal of pragmatics 40/4 (2008), 792-821.

Chamani, Fariba - Zareipur, Parvane. "A cross-cultural study of apologies in British English and Persian”. Concentric: Studies in Linguistics 36/1 (2010), 133-153.

Cohen, Andrew D. - Olshtain, Elite. "Developin a measure of sociocultural competence: the case of apology 1". Language learning 31/1 (1981), 113-134.

Ercetin, N. G. Pragmatic transfer in the realization of apologies: The case of Turkish EFL learners. Turkey: Boğaziçi University, Istanbul, Unpublished MA Thesis, 1995.

Eslami, Zohreh R. "Face-keeping strategies in reaction to complaints: English and Persian", Journal of Asian Pacific Communication 14/1 (2004), 179-195.

Farashaiyan, Atieh - Amirkhiz, Seyed Yasin Yazdi. "A Descriptive-Comparative Analysis of Apology Strategies: The Case of Iranian EFL and Malaysian ESL University Students”. English Language Teaching 4/1 (2011), 224-229.

Garcia, Carmen. “Apologizing in English: Politeness strategies used by native and non-native speakers”. Multilingua 8 (1989), 3-20.

Ghanbari, Halimeh et al. "Investigating apology strategy among Kurdish bilinguals: a case study in Ilam”. Procedia-Social and Behavioral Sciences 199/ (2015), 204-210.

Harlow, Linda L. "Do they mean what they say? Sociopragmatic competence and second language learners". The Modern Language Journal $74 / 3$ (1990), 328-351.

Holmes, Janet. “Apologies in New Zealand English”. Language in Society 19/2 (1990), 155-199.

Intachakra, Songthama. "Contrastive pragmatics and language teaching: Apologies and thanks in English and Thai* T". RELC journal 35/1 (2004), 37-62.

Ishihara, Noriko. "Web-based curriculum for pragmatics instruction in Japanese as a foreign language: An explicit awareness-raising approach". Language Awareness 16/1 (2007), 21-40.

İstifçi, İlknur. "The Use of Apologies by EFL Learners”. English language teaching 2/3 (2009), 15-25.

Kasanga, Luanga A. - Lwanga-Lumu, Joy Christine. "Cross-cultural linguistic realisation of politeness: A study of apologies in English and Setswana". Journal of Politeness Research 3 (2007), 65-92.

Kasper, Gabrielle - Rose, Kenneth R. Pragmatic development in a second language. Michigan:Blackwell, 2002.

Kondo, Sachiko. "The development of pragmatic competence by Japanese learners of English; longitudinal study on interlanguage apologies". Sophia Linguistica, 41 (1997), 265-284.

Liebersohn, Y Yosef Z., Neuman, Yair, - Bekerman, Zvi. “Oh baby, it's hard for me to say I'm sorry: Public apologetic speech and cultural rhetorical resources". Journal of Pragmatics 36/5 (2004), 921-944.

Marshall, Martin N. "Sampling for qualitative research”. Family Practice 13/6 (1996), 522-525.

Olshtain, Elite. Apologies across languages; cross-cultural pragmatics: Requests and apologies, Norwood, NJ: Ablex, 1989, 155-173.

Olshtain, Elite - Cohen, Andrew. 'Apology: A Speech Act Set'. Sociolinguistics

and Language Acquisition 18 (1983), 35.

Ozy1ldırım, Iş11. "The level of directness in Turkish apology forms in relation to the level of education". Hacettepe Universitesi, Edebiyat Fakultesi Dergisi 27/1 (2010), 179-201.

Prachanant, Nawamin. Pragmatic transfer in responses to complaints by thai efl learners in the hotel business. Thailand: Suranaree University of Technology, Institute of Social Technology, School of English, Ph. D Thesis, 2006.

Reiter, Rosina Márquez. Linguistic politeness in Britain and Uruguay: A contrastive study of requests and apologies. Philadelphia: John Benjamins North America, 2000.

Sadeghi, Mohammad Reza. "A Cross-Linguistic Investigation of Language Apology Speech Act: A Case of Persian and Kurdish Children”. 
Journal of Languages and Culture 4/3 (2013), 30-38.

Schmidt, Richard W. - Richards, John C. "Speech acts and second language learning”. Applied Linguistics 1/2 (1980), 129-157.

Shardakova, Maria. "Intercultural pragmatics in the speech of American L2 learners of Russian: Apologies offered by Americans in Russian". Intercultural Pragmatics 2 (2005), 423-451.

Shoshana, Blum-Kulka - Olshtain, Elite. "Requests and apologies: A cross-cultural study of speech act realization patterns (CCSARP)". Applied linguistics 5/3 (1984), 196-213.

Shoshana, Blum-Kulka et al. 'Cross-Cultural Pragmatics: Requests and Apologies'. Grazer Linguistische Studien (1989), $349-357$.

Tanaka, Keiko. "Developing pragmatic competence: A learners- as-researchers approach”. TESOL Journal, 6/3 (1997), 14-18.

Tamanaha, Masako. Interlanguage speech act realization of apologies and complaints: The performances of Japanese L2 speakers in comparison with Japanese L1 and English L1 speakers. Los Angeles: University of California, Doctoral dissertation, 2003.

Trosborg, Anna. “Interlanguage pragmatics: Requests, complaints and apologies”. New York: Mouton de Gruyter, 1995.

Tunçel, Ridvan. Speech act realizations of Turkish EFL learners: A study on apologizing and thanking. Eskişehir: Anadolu University, Unpublished Ph.D Dissertation, 1999.

Vollmer, Helmut J. - Olshtain, Elite. "The language of apologies in German”. Cross-cultural pragmatics: Requests and apologies, 197-218, 1988.

Wolfson, Nessa. 'Rules of Speaking in Language and Communication'. London:

Longman, 1983.

Wolfson, N. Perspectives: Sociolinguistics and TESOL. Baston (Massachusetts): NH Pub. Inc, 1989. 